\title{
Initial assessment of natural diversity in Mexican fig landraces
}

\author{
M.T. García-Ruiz ${ }^{1}$, V.M. Mendoza-Castillo ${ }^{2}$, E. Valadez-Moctezuma ${ }^{2}$ and \\ A. Muratalla-Lúa ${ }^{3}$ \\ 'Recursos Genéticos y Productividad, Fisiología Vegetal, \\ Colegio de Postgraduados, Montecillo, México \\ ${ }^{2}$ Departamento de Fitoctecnia, Universidad Autónoma Chapingo, \\ Chapingo, México \\ ${ }^{3}$ Recursos Genéticos y Productividad, Colegio de Postgraduados, \\ Montecillo, México \\ Corresponding author: E. Valadez-Moctezuma \\ E-mail: evaladez@correo.chapingo.mx
}

Genet. Mol. Res. 12 (3): 3931-3943 (2013)

Received December 12, 2012

Accepted July 16, 2013

Published September 23, 2013

DOI http://dx.doi.org/10.4238/2013.September.23.12

ABSTRACT. The common fig (Ficus carica L.) was introduced into Mexico by Spanish Franciscan missionaries in the 16th century. It is widely assumed that Mexican figs are the Spanish cultivar Black Mission. We collected and propagated 12 fig plants from six landraces from different states in Central Mexico that represent different climate. All of them were grown in a greenhouse at Universidad Autónoma Chapingo, in the State of Mexico. During the experimental period, the greenhouse had an average temperature and relative humidity of $29.2^{\circ}$ $\pm 5.4^{\circ} \mathrm{C}(\mathrm{SEM})$ and $78.1 \pm 6.7 \%(\mathrm{SEM})$, respectively. Morphological characterization was done following a selected set of quantitative and qualitative descriptors established by the IPGRI. DNA analysis was based on a combination of ISSR and RFLP markers. We observed great diversity mainly in fruit weight (28.1-96.2 g), fruit shape (ovoid, pyriform), and neck length $(0.97-3.80 \mathrm{~cm})$, which could not be explained by environmental conditions such as temperature and relative humidity. The Nei and Li/Dice similarity coefficient between landraces was determined by cluster analysis using the UPGMA method. Based on the 
morphological characterization and DNA fingerprinting data presented in this study, our results showed that after hundreds of years, black figs have adapted to local environmental condition in Central Mexico, yielding at least six clearly distinct landraces that represent valuable and previously undescribed genetic diversity. We also suggested names for those landraces according to their location and established a basis for further agronomic and molecular characterization of fig landraces.

Key words: Genetic diversity; Morphological descriptors; DNA fingerprinting; Molecular markers

\section{INTRODUCTION}

Archaeobotanic analysis has revealed that the common fig (Ficus carica L.) was the first cultivated plant in the world, predating cereal domestication (Krislev et al., 2006), and was a symbol for both the Greek and Roman cultures (Grivetti and Applegate, 1997). The fig plant has been used for cultural, food and medicinal purposes, including recreational and sporting events (Grivetti and Applegate, 1997). The fruit is one of the most nutritious in the world due to its high content of sugars, minerals, vitamins and antioxidants (Slavin, 2006).

The fig center of origin has not been clearly established. However, recent molecular analysis suggests that the center of origin is present day Turkey (Karandeniz, 2009). Human migration contributed to the dispersal of the plant outside its natural area (Condit, 1955). Currently, the fig is cultivated in 48 countries around the world (FAO, 2010).

The fig is a floristic component of the family Moraceae, which includes 37 genera and more than 1100 species (Datwyler and Weiblen, 2004). The genus Ficus is distributed mainly in warm and temperate climates and consists of approximately 881 species (Kumar et al., 2011). For this reason, it is considered the most diverse plant genus in the world. Fig species are monoecious if male and female flowers are on the same plant, or dioecious if male and female flowers are on separate plants (Beck and Lord, 1988). Particularly, F. carica L. is a gynodioecious diploid species with 26 chromosomes, bearing either hermaphroditic or female flowers on separate plants (Storey, 1977). This characteristic is important for distinguishing fig types and cultivars (Toribio and Montes, 1996).

Four fig types have been described on the basis of pollination type and number of crops produced per year. Common figs are parthenocarpic, fruits have no seeds, and produce only one crop per year (Melgarejo, 2000). Smyrna figs require pollination, fruits have seeds, and produce only one crop per year (Toribio and Montes, 1996). San Pedro figs are parthenocarpic in the first crop and require pollination in the second crop (Melgarejo, 2000). Caprifigs produce three crops per year but they are not edible; they are used as a source of pollen (Ilgin et al., 2007).

Approximately 607 fig cultivars have been described to date (Condit, 1955; Toribio and Montes, 1996; Álvarez-Arbesú and Fernández-Prieto, 2000). Forty-six are the most cultivated around the world (Flaishman et al., 2008), and 28 have been described as low-temperature resistant (Price and White, 1902). Commercially, the most common cultivars are: Sarylop, Conadria, Verde, San Pietro and Tsapela; all of them belong to the Smyrna type (Piga et al., 2003; El-Gharably et al., 2009; Sen et al., 2010; Xanthopoulos et al., 2010). 
Characterization of fig cultivars is based on a combination of qualitative and quantitative agronomic traits and morphological and chemical attributes (IPGRI, 2003). The most common features are growth habit (erect, semierect, spreading or erect-spreading), number of crops per year, pollination, shoot length and width, length of central lobe, petiole and leaves, fruit length, width, weight, stank and neck length, skin color, pulp color, flavor, juiciness, firmness, soluble solids (\%), total acidity, dry matter, $\mathrm{pH}$, mineral content and total sugar content (Ersoy et al., 2008; Aljane and Ferchichi, 2009).

Plant species and cultivar identifications have been improved by DNA fingerprinting purposes. Since 1980, twelve kinds of molecular markers have been developed. The most common are restriction fragment length polymorphism (RFLP), random amplification of polymorphic DNA (RAPD), inter-simple sequence repeats (ISSR), amplified fragment length polymorphism (AFLP) and microsatellites (Sarwat, 2012). ISSR were developed in 1994 from microsatellite regions of 16 to $18 \mathrm{bp}$ long (Chatti et al., 2010). ISSR gained popularity because they are highly polymorphic, flank highly conserved sequences, and are very useful for assessing natural variation in plants (Sarwat, 2012). Multiple papers confirm the effectiveness of ISSR in different species, such as chrysanthemum (Palai and Rout, 2011), grape (Hassan et al., 2011), and rose (Jabbarzadeh et al., 2010). Today, ISSR are considered one of the best options for DNA fingerprinting, assessment of genetic diversity between closely related individuals, genetic stability, gene tagging, hybrid and cultivar identification, somaclonal variation and production quality (Jabbarzadeh et al., 2010; Chatti et al., 2010; Sarwat, 2012). Specifically for fig, ISSR have been used for varietal identification (Khadari et al., 2003) to determine phylogenic relationships between cultivars (Guasmi et al., 2006) and to determine the genetic structure of cultivars (Aradhya et al., 2010).

The fig plant was introduced into Mexico in 1683 by Spanish Franciscan missionaries (Storey, 1977). They planted black figs outside churches in the states of Hidalgo, Guanajuato, Morelos, San Luis Potosi and Zacatecas (Parra Lerma, 1996). Currently, figs grow in all states of Mexico. However, orchards are found only in 11 states (SIAP, 2010). There is no information about molecular characterization or natural diversity of fig landraces. It is widely assumed that Mexican figs are the Spanish Black Mission cultivar. In this study, we report previously undescribed natural variation in fruit morphology among black figs from different parts of Mexico. To assess genetic variation among black fig landraces from Central Mexico, we performed an initial morphological characterization and DNA fingerprinting analysis based on a combination of ISSR and RFLP. Our results showed that black figs initially derived from Black Mission and have adapted to local environmental conditions in Central Mexico, yielding several, clearly distinct landraces, which represent valuable and previously undescribed genetic diversity.

\section{MATERIAL AND METHODS}

\section{Morphological characterization}

Six black fig landraces of the common type were collected from different states in Central Mexico. All of them were grown in a greenhouse at Universidad Autónoma Chapingo, in the state of Mexico. Morphological characterization was done following a selected set of descriptors (Table 1) established by the International Plant Genetic Resources Institute (IPGRI) in 2003. Accordingly, 20 mature fruits $(100 \%$ colored) of each landrace were randomly picked 
in the middle of the harvest season (July, 2012). During this period, the greenhouse had an average temperature and relative humidity of $29.2^{\circ} \pm 5.4^{\circ} \mathrm{C}(\mathrm{SEM})$ and $78.1 \pm 6.7 \%$ (SEM), respectively. Fruit shape, fruit pulp internal color, flesh color, firmness, ease of peeling, shape and abscission of the stalk, size of ostiolum, and fruit apex and cavity, were recorded based on qualitative scales (Table 1). Fruit weight (g) was measured using a balance sensitive to $0.1 \mathrm{~g}$ (OHAUS, USA). Length and width of the fruit, and neck length and stalk $(\mathrm{cm})$ were measured with a digital vernier (Mitutoyo ${ }^{\circledR}$, Japan).

\section{DNA extraction}

Twelve plants were sampled from each of the six landraces. Leaves were collected from the apex of each plant. Tissue from plants was pooled to get four samples of $3.0 \mathrm{~g}$. Leaves were ground in liquid nitrogen and the DNA extracted following the CTAB method (Weising et al., 2005) with minor modifications (4\% CTAB and 1 volume of $100 \%$ isopropanol). DNA concentration was determined by spectrophotometry (Thermo Scientific Nanodrop ND-1000, USA) and standardized to $150 \mathrm{ng} / \mu \mathrm{L}$.

\section{Design of Fruitfull-based primers}

One forward (Fruitfull_F131) and two reverse primers (Fruitfull_R1218 and Fruitfull_R3056) were designed on the basis of Arabidopsis thaliana gene No. ATG560910 (Fruitfull) (Figure 1) downloaded from The Arabidopsis Information Resource Database (www.arabidopsis.org). To do this, Fruitfull cDNA sequence was aligned with other plant species using BLAST (www.ncbi.nlm.nih.gov). Primers were chosen from sequences highly conserved across plant species (Figure 1).

\section{Polymerase chain reaction $(\mathrm{PCR})$}

PCR was performed with four of 18 individual ISSR primers tested in fig by Kadhari et al. (2004) and Chatti et al. (2010), or with a pair of Fruitfull-based primers. PCR was done in a thermal cycler (MaxyGene Gradient Axygen, Brazil). Components of the PCR mix (25 $\mu \mathrm{L}$ ) were as follows: $300 \mathrm{ng}$ genomic DNA, $1 \mathrm{mM} \mathrm{MgSO}_{4}, 0.25 \mathrm{mM}$ dNTPs, $0.4 \mu \mathrm{M}$ primer, $1 \mathrm{X}$ ThermoPol buffer and $1 \mathrm{U}$ Taq DNA polymerase (Invitrogen). PCR cycling conditions for ISSR were: $95^{\circ} \mathrm{C}$ for $5 \mathrm{~min}$ for initial denaturation; 35 cycles at $95^{\circ} \mathrm{C}$ for $1 \mathrm{~min}, 42^{\circ} \mathrm{C}$ for $45 \mathrm{~s}$ and $68^{\circ} \mathrm{C}$ for $1 \mathrm{~min}$ and $40 \mathrm{~s}$; and $68^{\circ} \mathrm{C}$ for $5 \mathrm{~min}$ for final extension. PCR cycling conditions for Fruitfull primers were: $95^{\circ} \mathrm{C}$ for $5 \mathrm{~min}$ for initial denaturation; 35 cycles at $95^{\circ} \mathrm{C}$ for $1 \mathrm{~min}$, $40^{\circ} \mathrm{C}$ for $45 \mathrm{~s}$ and $68^{\circ} \mathrm{C}$ for $3 \mathrm{~min}$ and $15 \mathrm{~s}$; and $68^{\circ} \mathrm{C}$ for $5 \mathrm{~min}$ for final extension. Three biological replicates were processed for each landrace and primer combinations. Only one ISSR amplified fig genomic DNA (Table 2).

Undigested PCR products for both ISSR and Fruitfull primers were mixed with $10 \mu \mathrm{L}$ 6X bromophenol-blue loading dye. A volume of $15 \mu \mathrm{L}$ mix was loaded on a $1 \%$ agarose gel submersed in $1 \mathrm{X}$ Tris-sodium acetate-EDTA (TAE) buffer. GeneRuler $100 \mathrm{bp}$ Plus (10 $\mu \mathrm{L})$ and $1 \mathrm{~kb}$ Plus DNA ladder (Thermo Scientific) $(10 \mu \mathrm{L})$ were used as standard molecular weight markers. Electrophoresis was run on a genetic analyzer (Cleaver scientific Ltd, USA) for 45 min at $85 \mathrm{~V}$. The gels were stained with ethidium bromide and photographed using a Gel Doc XR Universal Hood II (Bio-Rad, USA). 
A BLAST alignment of A. thaliana Fruitfull

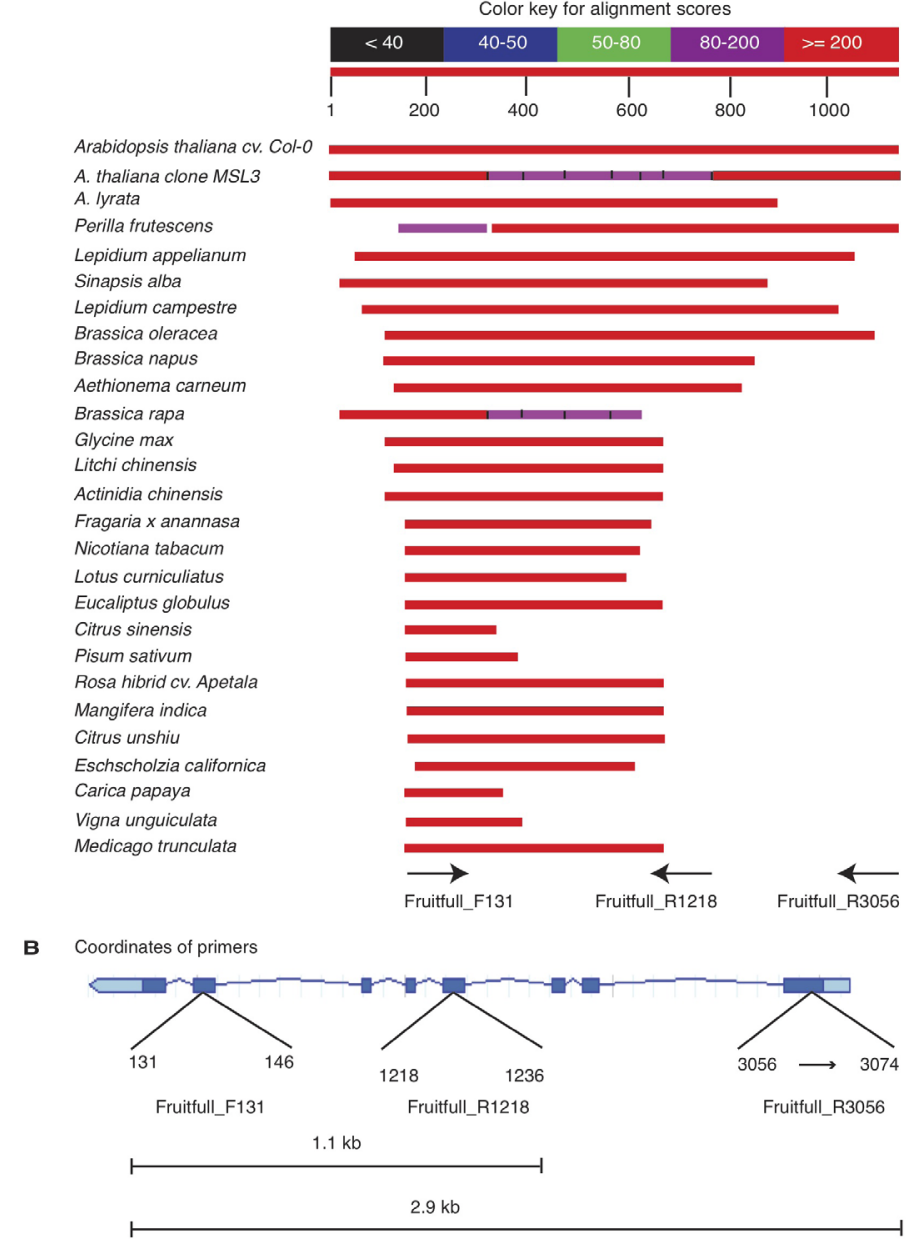

Figure 1. Design of primers using Arabidopsis thaliana cDNA sequence of gene AT5G60910 (Fruitfull). A. BLAST alignment of $A$. thaliana Fruitfull cDNA to several plant species. Arrows indicate the position from which one forward and two reverse primers were derived. B. Coordinates of primers used based on the genomic sequencing for Fruitfull.

\section{Restriction digestion}

PCR products $(25 \mu \mathrm{L})$ were double-digested with $B g l \mathrm{II}$ and $B a m \mathrm{HI}$ restriction enzymes at $37^{\circ} \mathrm{C}$ for $3 \mathrm{~h}$. Digested PCR products were mixed with $10 \mu \mathrm{L} 6 \mathrm{X}$ bromophenolblue loading dye. A volume of $20 \mu \mathrm{L}$ mix was loaded on a $6 \%$ native polyacrylamide gel in $0.5 \mathrm{X}$ TBE buffer. The standard molecular weight markers used were the same as above. Electrophoresis was run on a vertical Dual TMVG-216-33 gel rig (C.B.S. Scientific, USA), for $150 \mathrm{~min}$ at $100 \mathrm{~V}$. Gels were stained with Sybergold (Invitrogen) and photographed under ultraviolet light. 


\section{Data analysis}

The electrophoresis pattern obtained after restriction digestion was analyzed in two parts. First, the size of the bands was estimated using the DNA markers. Second, band patterns observed for each primer combination were assigned to a binary system of 0 and 1 . We assigned 0 if a band was absent and 1 if a band was present. The Nei and Li/Dice similarity coefficient among landraces was determined by cluster analysis using the unweighted pair group method with arithmetic mean (UPGMA) in FreeTree software (v0.9.1.50) and Tree View (v1.6.6).

\section{RESULTS AND DISCUSSION}

\section{Morphological characterization}

In an effort to register the natural diversity among fig landraces in Mexico, we established a germplasm collection at Universidad Autónoma Chapingo, in the state of Mexico. This is the first and only collection of fig landraces in Mexico and currently consists of six landraces coming from different parts of Central Mexico. Plants were grown in a greenhouse at the Horticulture Experiment Station (Department of Plant Science). At their places of origin, the landraces are called Black Mission. Characterization of fruit morphology showed that there is great natural variation among landraces (Table 1). The main differences are fruit size, fruit shape, and neck length (Figure 2).

\begin{tabular}{|c|c|c|c|c|c|c|}
\hline Descriptor & Ixmiquilpan & Salvatierra & Tecámac & Tetela & Neza & Zacapala \\
\hline Origin & Hidalgo & Guanajuato & Mexico State & Morelos & Mexico State & Puebla \\
\hline Shape & Pyriform & Pyriform & Ovoid & Ovoid & Piryform & Ovoid \\
\hline Pulp intern color & Red & Red & White/Yellow & Pink & Red & Red \\
\hline Flesh color & Light & Light & None & Light & Light & Light \\
\hline Firmness & Firm & Medium & Firm & Medium & Soft & Firm \\
\hline Ease of peeling & Medium & Easy & Hard & Medium & Easy & Hard \\
\hline Shape of the stalk & Long and slender & Short and thick & Short and thick & Long and slender & Variosly enlarged & Short and thick \\
\hline Abscission of the stalk & Hard & Easy & Easy & Hard & Easy & Hard \\
\hline Size of ostiolum & Small & Small & Small & Medium & Big & Small \\
\hline Apex & Rounded & Rounded & Flat & Rounded & Rounded & Rounded \\
\hline Cavity & None & Very small & None & Medium & Small & Large \\
\hline
\end{tabular}

The weather plays an important role in the expression of the morphological characteristics of plants (Price and White, 1902; Storey, 1977). However, our results showed that the natural diversity of Mexican black fig landraces could not be explained by the weather, because we grew all plants under the same environmental conditions.

We cannot rule at the possibility at some point that the landraces we describe here shared a common ancestor. However, today they are different. For identification purposes, we assigned a name to each landrace (Table 1) on the basis of their place of origin. Using a combination of fruit features (Table 1 and Figure 2), their main characteristics are as follows: Tecámac, ovoid fruits with yellow pulp and no cavity; Zacapala, ovoid fruits with large cavity and short and thick stalk; Salvatierra, pyriform fruit with red pulp and very small cavity; 
Tetela, ovoid fruits with pink pulp, very long neck and slender stalk; Ixmiquilpan, pyriform fruits with red pulp, long neck, slender stalk and no cavity; and Neza, soft pyriform fruits of very large size with red pulp, long neck, enlarged stalk and big ostiolum.

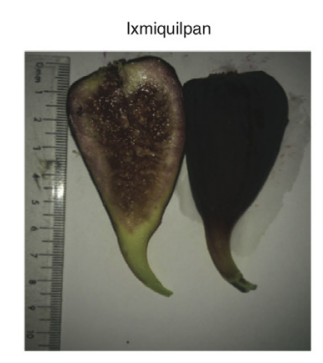

Tetela

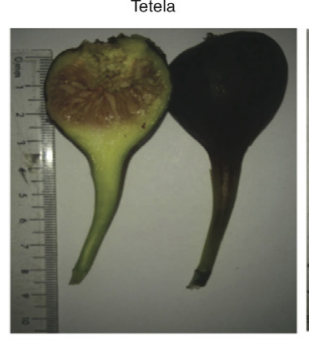

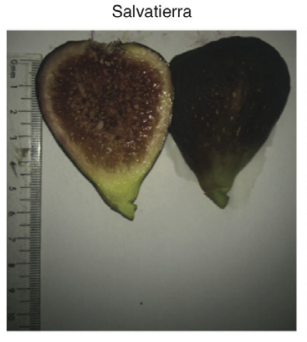

Neza

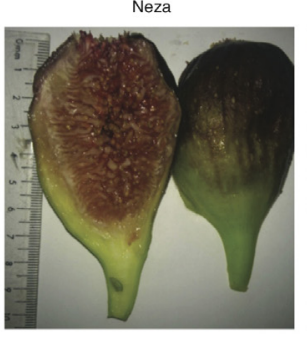

Tecámac

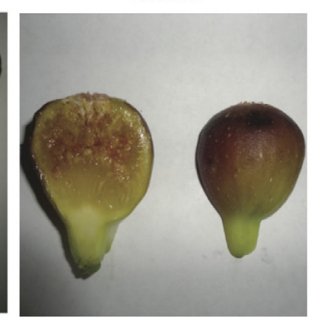

Zacapala

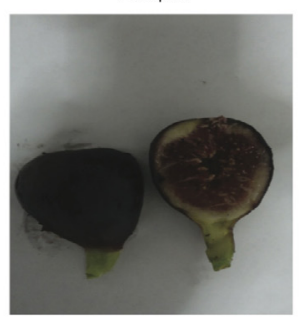

Figure 2. Representative pictures showing fruit characteristics for several fig landraces from Mexico.

Descriptors for fig fruits in general (IPGRI, 2003) and specifically for cultivars Sarylop and Black Mission are available (Condit, 1955; Storey, 1977; Ersoy et al., 2008; CFAB, 2011; Oguzhan and Atila, 2012). We used the IPGRI quantitative references and both Sarylop and Black Mission cultivars, as standards to compare the Mexican landraces described here. Significant variation in fruit size was observed among landraces (Figure 3). However, five landraces were in the range for minimum and maximum values described for fruit size (weight, length, width and neck length). Tecámac and Zacapala produced small fruits. Interestingly, Neza produced the biggest and heaviest fruits that were even bigger and heavier than Sarylop and Black Mission (Condit, 1955; Storey, 1977; Ersoy et al., 2008; Oguzhan and Atila, 2012). It is possible that differences between Neza and the international standards were due to environmental conditions. Our results were obtained using plants grown in a greenhouse, while the international standards were derived from field conditions. Nevertheless, our results showed that the Neza landrace has a high potential for commercial production. In agreement with this conclusion, in Mexico, the yield in traditional agriculture for figs varies from 5 to 7 tons per hectare (SIAP, 2010). However, for Neza we estimated that under greenhouse conditions it is possible to obtain 120 tons per hectare per year.

\section{ISSR DNA fingerprinting}

The landraces described here showed clearly distinct fruit characteristics when growing under the same environmental conditions (Figure 2). Thus, we hypothesized that those landraces are genetically different. To test this hypothesis we did a DNA fingerprinting analy- 
sis based on a combination of ISSR and RFLPs. Out of 18 ISSR primers tested, only four generated abundant PCR products visible on a $1 \%$ agarose gel (Figure $4 \mathrm{~A}$ ). A prominent band was present at $750 \mathrm{bp}$. However, less abundant bands were present between 1 and $2 \mathrm{~kb}$. Interestingly, BglII-BamHI double digestion of PCR product yielded an electrophoresis pattern that clearly distinguished all landraces (Figure 4B). A total of 14 bands, 10 of them polymorphic, were observed between $75 \mathrm{bp}$ and $1.5 \mathrm{~kb}$. Tetela had a distinctive band at a position higher than $1.5 \mathrm{~kb}$. Salvatierra had two distinctive bands at 90 and $150 \mathrm{bp}$. Ixmiquilpan had one distinctive band at $150 \mathrm{bp}$. Zacapala lacked a band at $90 \mathrm{bp}$ and one other at $1.4 \mathrm{~kb}$. Tecámac lacked a band at $150 \mathrm{bp}$ and had a distinctive band at $1.0 \mathrm{~kb}$. Neza lacked tree bands, one at $90 \mathrm{bp}$, another at $150 \mathrm{bp}$, and another at $1.0 \mathrm{~kb}$.

A Fruit weight

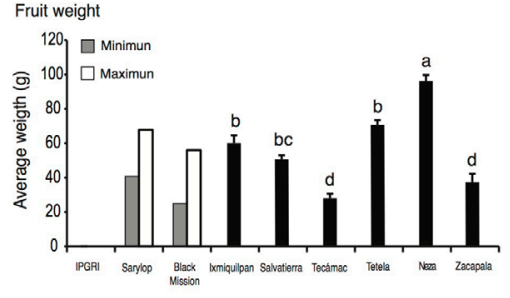

B Fruit length

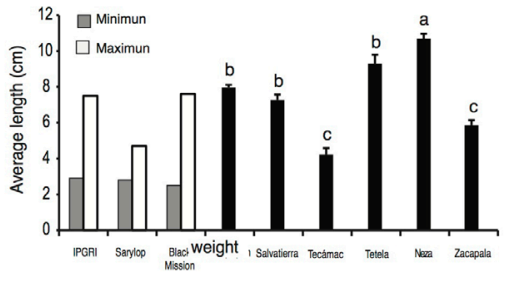

C Fruit width

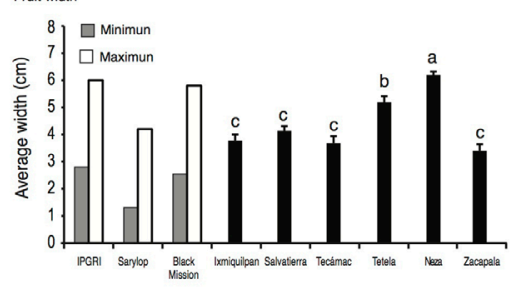

D Fruit length of neck

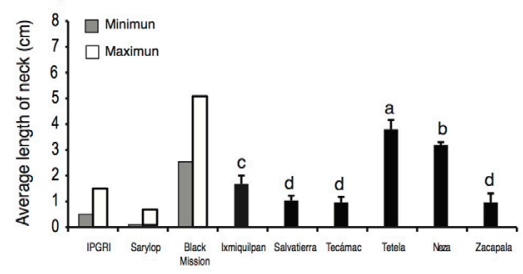

Figure 3. Fruit size for several fig landraces from Mexico compared to fig international standards (IPGRI, 2003), Sarylop (Ersoy et al., 2008; Oguzgan and Atila, 2012) and Black Mission (Condit, 1955; Storey, 1977; CFAB, 2011). Black bars represent the means $( \pm S E M, N=20)$. A. Fruit weight in grams $(g)$. B. Fruit length in centimeters $(\mathrm{cm})$. C. Fruit width $(\mathrm{cm})$. D. Length of fruit neck $(\mathrm{cm})$. Bars with the same letter are not statistically different by the Tukey test $(\mathrm{P} \leq 0.05, \mathrm{~N}=20)$. 
A

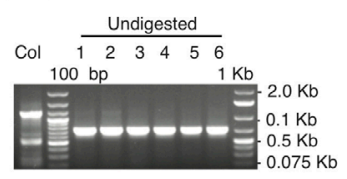

B

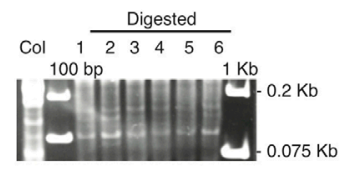

C Phylogenetic tree

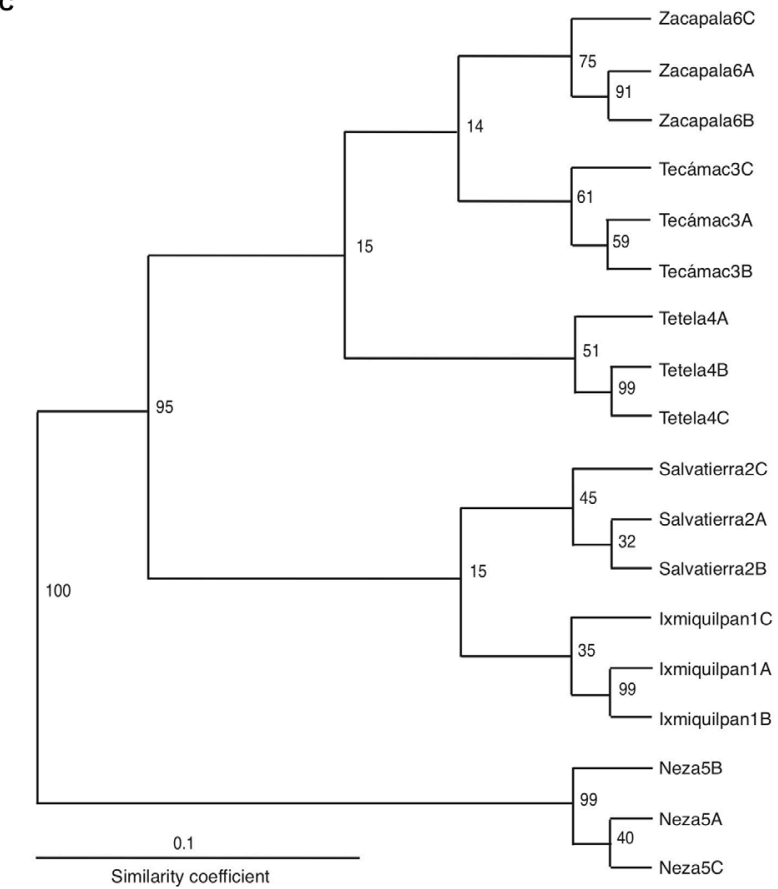

Figure 4. DNA fingerprinting analysis of fig landraces from central Mexico using ISSR primers. Arabidopsis thaliana ecotype Columbia (Col-0) was included as control. A. Electrophoresis patterns of undigested PCR products run on $1 \%$ agarose gels. B. BglII-BamHI digested PCR products run on $6 \%$ native polyacrilamide gels. $100 \mathrm{bp}$ and $1 \mathrm{~Kb}$ DNA ladders were used as size markers. C. Phylogenetic tree (bootstrap = 200) based on the electrophoresis pattern of $\mathbf{A}$ and $\mathbf{B}$. Landraces are identified by numbers in $\mathbf{A}$ and $\mathbf{B}$ that correspond to names with three repetitions $(\mathrm{A}, \mathrm{B}, \mathrm{C})$ in $\mathbf{C}$.

Using the electrophoresis pattern, we estimated the Nei and Li/Dice similarity coefficient using UPGMA. The cluster analysis discriminated all the landraces evaluated in this study. On the basis of these results, we concluded that the landraces described here (Ixmiquilpan, Neza, Salvatierra, Tecámac, Tetela and Zacapala) are genetically different. However, the phylogenetic tree and similarity coefficient obtained (Figure 4C) had no correlation with fruit characteristics (Figure 2). One explanation for the lack of correlation is that in addition to fruit morphology, the landraces described here are different in several characteristics such as sugar content, firmness, flavor, anthocyanin and polyphenol content, resistance to pests or diseases, and resistance to low temperature or drought. In support of this conclusion, we observed that Ixmiquilpan has the hardest fruit while Neza has a soft fruit. Tecámac is the most droughtresistant compared to the others. Tetela is the most sensitive to low temperatures. 


\section{Fruitfull-based DNA fingerprinting}

Today, the main difference between the landraces described here is fruit morphology. No information is available for genes determining fruit characteristics in fig. However, in the model plant Arabidopsis thaliana, 27 genes are responsible for the development of fruit characteristics (Roeder and Yanofsky, 2006). Interestingly, the gene responsible for fruit size (Fruitfull) is highly conserved in plants (Figure 1A). Thus, we hypothesized that figs have a Fruitfull homolog. To test this hypothesis, we generated one forward and two reverse primers based on Fruitfull sequences (Figure 1B) and used them for PCR on fig genomic DNA. In all landraces, these primers yielded a prominent PCR product measuring approximately $900 \mathrm{bp}$ (Figure 5). However, additional bands were seen between 200 and 500 bp.

Upon BglI-BamHI digestions, PCR products using primers Fruitfull_F131 and Fruitfull_R1218 or Fruitfull_F131 and Fruitfull_R3056 generated several polymorphic bands (Table 2) that clearly distinguished all landraces. In the area between 75 and $200 \mathrm{bp}$, digested PCR products generated using primers Fruitfull_F131 and Fruitfull_R1218 revealed clear differences between landraces (Figure 5A).

\begin{tabular}{|c|c|c|c|c|c|c|c|}
\hline \multirow[t]{2}{*}{ Name } & \multirow[t]{2}{*}{ Sequence (5' to $3^{\prime}$ ) } & \multirow[t]{2}{*}{ Kind } & \multirow[t]{2}{*}{$\mathrm{T}_{\mathrm{m}}{ }^{\mathrm{a}}$} & \multirow[t]{2}{*}{$A_{t}^{b}$} & \multicolumn{2}{|c|}{ Bands } & \multirow[t]{2}{*}{$\%^{d}$} \\
\hline & & & & & Total $^{c}$ & Polymorphic & \\
\hline$(\mathrm{AGAC})_{4} \mathrm{GC}$ & AGACAGACAGACAGACGC & ISSR & 54 & 49 & 24 & 12 & 50.00 \\
\hline$(\mathrm{GACA})_{4} \mathrm{GT}$ & GACAGACAGACAGACAGT & ISSR & 51 & 46 & 18 & 15 & 83.33 \\
\hline$(\mathrm{CA})_{8} \mathrm{AGC}$ & CACACACACACACACAAGT & ISSR & 53 & 48 & 17 & 7 & 41.18 \\
\hline$(\mathrm{ACTG})_{4}$ & ACTGACTGACTGACTG & ISSR & 47 & 42 & 14 & 10 & 71.42 \\
\hline Fruitfull_F131 & ATGGGAAGAGGTAGGG & RFLP (Gene specific) & 58 & 53 & - & - & - \\
\hline Fruitfull_R1218 & GATACTTGAACGCTATGAT & RFLP (Gene specific) & 45 & 40 & 22 & 5 & 22.72 \\
\hline Fruitfull_R3056 & GATTAAGGAGAGGGAGAAG & RFLP (Gene specific) & 48 & 43 & 26 & 10 & 38.46 \\
\hline
\end{tabular}

${ }^{a}$ Melting temperature. ${ }^{\mathrm{b}}$ Anneling temperature. ${ }^{\mathrm{c} S u m m a r y}$ of electrophoresis pattern of BglII-BamHI digested PCR products using Fruitfull_F131 and Fruitfull_R1218, and Fruitfull_F131 and Fruitfull_R3056 primer combinations. dPolymorphism percentage.

Neza lacked two bands between 100 and $150 \mathrm{bp}$. Ixmiquilpan lacked a band at $150 \mathrm{bp}$ and had an additional band at $75 \mathrm{bp}$. Tetela lacked a band at $150 \mathrm{bp}$. Tecámac had two bands very close to each other at $150 \mathrm{bp}$. Salvatierra and Zacapala were very similar, but clearly differed with regard to the digested PCR products generated using primers Fruitfull_F131 and Fruitfull_R3056 (Figure 5B). Salvatierra had a band at 45 bp that Zacapala lacked.

On the basis of the electrophoresis pattern observed from both sets of digested PCR products (primers Fruitfull_F131 and Fruitfull_R1218 and Fruitfull_131 and Fruitfull_R3056), we estimated the Nei and $\bar{L}$ i/Dice similarity coefficient using UPGMA. Cluster analysis (Figure 5C) discriminated all landraces. These results confirmed that the landraces described here (Ixmiquilpan, Neza, Salvatierra, Tecámac, Tetela and Zacapala) are genetically different. In addition, the phylogenetic tree and genetic distance obtained (Figure 5C) showed high correlation with fruit characteristics (Figure 2). These results suggest that fig has a Fruitfull homolog that determines fruit size and that the Mexican landraces described here have accumulated mutations in that gene.

Black fig in Mexico derived from Black Mission. However, after hundreds of years from the time of introduction, fig plants have adapted to different environmental conditions. In this paper, we present tree lines of evidences showing that black fig populations in Central Mexico represent clearly different landraces: 
1. Fruit characteristics (Figure 2).

2. ISSR-based DNA fingerprinting.

3. Fruitfull-based DNA fingerprinting.

We do not know the genetic distance between Mexican landraces and cultivar Black Mission. However, using the methodology described here, that distance could be determined. Additionally, the same methodology could be used for characterizing additional landraces from Mexico and possibly other plant species.

A Fruitfull_F131 and R_1218

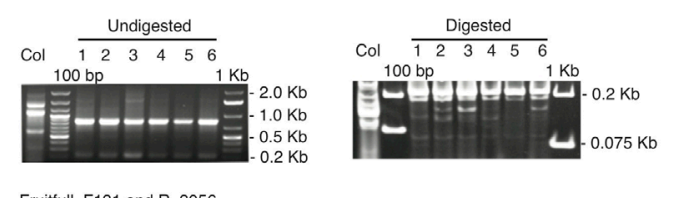

B Fruitfull_F131 and R_3056

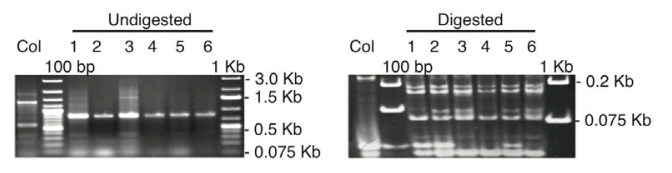

C Phylogenetic tree

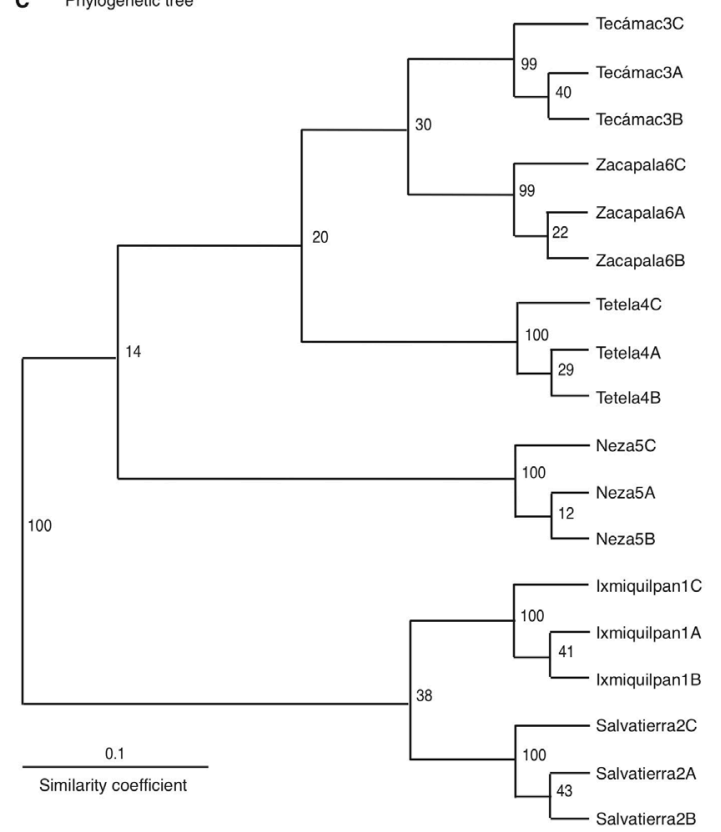

Figure 5. DNA fingerprinting analysis of fig landraces from central Mexico. Arabidopsis thaliana ecotype Columbia (Col-0) was included as control. A. and B. show electrophoresis patterns of PCR products generated using primers Fruitfull_F131 and Fruitfull_R1218, and Fruitfull_F131 and Fruitfull_R3056 respectively. Undigested PCR products were run on $1 \%$ agarose gels (left panel). BglII-Bam HI digested PCR products were run on $6 \%$ native polyacrilamide gels. $100 \mathrm{bp}$ and $1 \mathrm{~Kb}$ DNA ladders were used as size markers. C. Phylogenic tree (bootstrap = 200) based on the electrophoresis pattern of $\mathbf{A}$ and $\mathbf{B}$. Landraces are identified by numbers in $\mathbf{A}$ and $\mathbf{B}$ that correspond to names with three repetitions $(\mathrm{A}, \mathrm{B}, \mathrm{C})$ in $\mathbf{C}$. 


\section{ACKNOWLEDGMENTS}

Mayra Teresa García Ruiz was the recipient of a graduate student fellowship from CONACYT (\#175298). We thank Dr. Jim Carrington for hosting MTGR for a graduate student internship at the Donald Danforth Plant Science Center and Dr. Hernan Garcia-Ruiz for personally guiding MTGR through many aspects in the science field. We are grateful to Henry Wagaba, graduate student at Donald Danforth Plant Science Center, for assistance with data analysis.

\section{REFERENCES}

Aljane F and Ferchichi A (2009). Postharvest chemical properties and mineral contents of some fig (Ficus carica L.) cultivars in Tunisia. J. Food Agric. Environ. 7: 209-212.

Aradhya MK, Stover E, Velasco D and Koehmstedt A (2010). Genetic structure and differentiation in cultivated fig (Ficus carica L.). Genetica 138: 681-694.

Álvarez-Arbesú R and Fernández-Prieto JA (2000). Poblaciones silvestres de higueras, vides y olivos en la costa cantábrica. Consideraciones acerca de su origen. Naturalia Cantabricae 1: 33-43.

Beck NG and Lord EM (1988). Breeding system in Ficus carica, the common fig II. Pollination events. Am. J. Bot. 75: 1913-1922.

CFAB (2011). Industry Overview. Available at [http://californiafigs.com/uploads/FIG\%20FACTS\%202011.pdf]. Accessed June 30, 2012.

Chatti K, Baraket G, Ben AA, Saddoud O, et al. (2010). Development of molecular tools for characterization and genetic diversity analysis in Tunisian fig (Ficus carica) cultivars. Biochem. Genet. 48: 789-806.

Condit IJ (1955). Fig varieties: A monograph. Hilgardia 23: 323-539.

Datwyler SL and Weiblen GD (2004). On the origin of the fig: phylogenetic relationships of Moraceae from ndhF sequences. Am. J. Bot. 91: 767-777.

El-Gharably AM, Nagib AI and Rizk EM (2009). Evaluation of quality attributes for Egyptian apricot and fig cultivars produced by osmodrying process. Ann. Agric. Sci. 54: 359-369.

Ersoy N, Gözlekci S, Kaynak L, Dal B, et al. (2008). Relationship among the shoot, leaf and fruit growth of some fig (Ficus carica) cultivars grown in Antalya conditions. Acta Hort. 798: 143-148.

FAO (2010). Statistical Yearbook. Agricultural Production. Available at [http://faostat.fao.org/site/567/DesktopDefault. aspx?PageID=567\#ancor]. Accessed May 15, 2012.

Flaishman MA, Rodov V and Stover E (2008). The fig: botany, horticulture, and breeding. Hortic. Rev. 34: 113-196.

Grivetti LE and Applegate EA (1997). From Olympic to Atlanta: a cultural-historical perspective on diet and athletic training. J. Nutr. 127: 860-868.

Guasmi F, Ferchichi A, Farés K and Touil L (2006). Identification and differentiation of Ficus carica L. cultivars using inter simple sequence repeat markers. Afr. J. Biotechnol. 5: 1370-1374.

Hassan HA, El-Homosany AG, Amina H and Shaheen MA (2011). Morphological and ISSR polymorphisms in some Egyptian grapes (Vitis vinefera L.) collection. World Appl. Sci. J. 15: 1369-1375.

Ilgin M, Ergenoglu F and Caglar S (2007). Viability, germination and amount of pollen in selected caprifig types. Pak. J. Bot. 39: 9-14.

IPGRI (2003). Descriptors for Fig. International Plant Genetic Resources Institute, Rome, Italy, and International Centre for Advanced Mediterranean Agronomic Studies, Paris, France.

Jabbarzadeh Z, Khosh-khui M, Salehi H and Saberivand A (2010). Inter simple sequence repeat (ISSR) markers as reproducible and specific tools for genetic diversity analysis of rose species. Afr. J. Biotechnol. 9: 6091-6095.

Karandeniz T (2009). Clonal Selection in Siyah Fig cv. at Black Sea Region of Turkey. In: Fourth International Symposium on Fig. Meknes, Morocco

Khadari B, Hochu I, Santoni S, Ater M, et al. (2003). Which molecular markers are best suited to identify fig cultivars: a comparison of RAPD, ISSR and microsatellite markers. Acta Hortic. 605: 69-75.

Krislev ME, Hartmann A and Bar-Yosef O (2006). Early domesticated fig in the Jordan Valley. Science 312: 1373-1374.

Kumar A, Bajpai O, Mishra AK, Sahu N, et al. (2011). Assessment of diversity in the genus Ficus L. (Moraceae) of Katerniaghat Wildlife Sanctuary, Uttar Pradesh, India. Am. J. Plant Sci. 2: 78-92.

Melgarejo MP (2000). Tratado de Fruticultura para Zonas Áridas y Semiáridas. Vol I. Ediciones Madrid Vicente y MundiPrensa. Madrid, España. 
Oguzhan C and Atila AP (2012). Morphological diversity among fig (Ficus carica L.) accessions sampled from the Eastern Mediterranean Region of Turkey. Turk. J. Agric. For. 36: 179-193.

Palai SK and Rout GR (2011). Characterization of new variety of Chrysanthemum by using ISSR markers. Hortic. Bras. 29: 613-617.

Parra Lerma J (1996). Estudio Fenológico de un Huerto de Higuera (Ficus carica L.) en el Ejido Francisco Villa, Municipio de Comundu, Baja California Sur. Tesis de Licenciatura. Facultad de Agricultura, Universidad Autónoma de Nayarit.

Piga A, Agabbio M and Farris GA (2003). Dehydration performance of local fig cultivars. Acta Hort. 605: 241-245.

Price RH and White EA (1902). The Fig. Bulletin No. 62. Agricultural Experimental Stations. College Station, Brazos Country.

Roeder AHK and Yanosfky MF (2006). Fruit Development in Arabidospsis. The Arabidopsis Book, Number 4. American Society of Plant Biologist. Available at [http://www.bioone.org/doi/full/10.1199/tab.0075]. Accessed September 7, 2012.

Sarwat M (2012). ISSR: Plant DNA Fingerprinting and Barcoding: Methods and Protocols. In: A Reliable and CostEffective Technique for Detection of DNA Polymorphism (Sucher NJ, Hennell JR and Carles MC, eds.). Methods Mol. Biol. 862: 103-121.

Sen F, Meyvaci KB, Turanli F and Aksoy U (2010). Effects of short-term controlled atmosphere treatment at elevated temperature on dried fig fruit. J. Stored Prod. Res. 46: 28-33.

SIAP (2010). Anuario Estadístico de la Producción Agrícola. Mexico, D.F. Available at [http://www.siap.gob.mx/index. php?option=com_wrapper\&view=wrapper\&Itemid=351]. Accessed October 13, 2012.

Slavin JL (2006). Figs: past, present and future. Nutr. Today 41: 180-184.

Storey WB, Enderud JE, Saleeb WF and Nauer EM (1977). The Fig: Its Biology, History, Culture and Utilization. Jurupa Mountains Cultural Center, Riverside.

Toribio F and Montes P (1996). Variedades de la higuera. Vida Rural 27: 92-96.

Weising K, Nybom H, Wolff K and Kahl G (2005). DNA Finger Printing in Plant: Principles, Methods, and Applications. Second edn. CRC Press Taylor \& Francis Group, Florida.

Xanthopoulos G, Yanniotis S and Lambrinos G (2010). Study of the drying behavior in peeled and unpeeled whole figs. J. Food Eng. 97: 419-424. 